\title{
Effects of carcass weight increase on meat quality and sensory pro- perties of pork loin
}

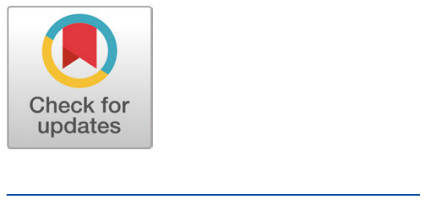

Received: Aug 13, 2020

Revised: Sept 10, 2020

Accepted: Sept 14, 2020

\#These authors contributed equally to this work.

${ }^{*}$ Corresponding author

Seon-Tea Joo

Division of Applied Life Science (BK21 ${ }^{+}$)

Gyeongsang National University,

Jinju 52828, Korea.

Tel: +82-55-772-1943

E-mail: stjoo@gnu.ac.kr

Copyright $\odot 2020$ Korean Society of

Animal Sciences and Technology.

This is an Open Access article

distributed under the terms of the

Creative Commons Attribution

Non-Commercial License (http://

creativecommons.org/licenses/by-

$\mathrm{nc} / 4.0 /$ ) which permits unrestricted

non-commercial use, distribution, and

reproduction in any medium, provided

the original work is properly cited.

ORCID

Young-Hwa Hwang

https://orcid.org/0000-0003-3687-3535

Se-Jin Lee

https://orcid.org/0000-0001-6030-0601

Eun-Yeong Lee

https://orcid.org/0000-0002-3467-7349

Seon-Tea Joo

https://orcid.org/0000-0002-5483-2828

\section{Competing interests}

No potential conflict of interest relevant

to this article was reported.

Funding sources

This work was supported by the

National Research Foundation

of Korea (NRF) grant funded by

the Korea government (MSIT)

(No.2019R1I1A1A01061707).

\author{
Young-Hwa Hwang ${ }^{1 \#}$, Se-Jin Lee ${ }^{2 \#}$, Eun-Yeong Lee ${ }^{2}$ and Seon-Tea Joo ${ }^{1,2 *}$ \\ ${ }^{1}$ Institute of Agriculture \& Life Science, Gyeongsang National University, Jinju 52852, Korea \\ ${ }^{2}$ Division of Applied Life Science (BK21 ${ }^{+}$), Gyeongsang National University, Jinju 52852, Korea
}

\section{Abstract}

The objective of this study was to investigate the influence of increasing carcass weight (CW) on meat quality traits including meat color, water-holding capacity (WHC), tenderness, backfat thickness and intramuscular fat (IMF) content of pork loin. A total of 96 pork carcasses (48 LYD [Landrace $\times$ Yorkshire $\times$ Duroc] barrows and gilts) were selected at a commercial slaughterhouse. Each gender had commercial CW ( $\leq 90 \mathrm{~kg})$, heavy CW (91-100 kg) and very heavy CW (>100 kg) (16 carcasses from each CW group). Loin cuts (Longissimus lumborum) were excised to investigate meat color (CIE L*a*b*), drip loss, cooking loss, released water, Warner-Bratzler shear force (WBSF), and IMF content. Backfat thickness and IMF content of pork loin samples were significantly $(p<0.05)$ increased with increasing CW, although there was no significant difference in ultimate $\mathrm{pH}(\mathrm{pHu})$. CIE $a^{*}$ increased significantly $(p<0.05)$ with increasing $\mathrm{CW}$, while there were no significant differences in $\mathrm{CIE} \mathrm{L}^{*}$ or $\mathrm{CIE} \mathrm{b}^{*}$ among $\mathrm{CW}$ groups. Although all WHC measures showed no significant differences among CW groups, WBSF increased significantly $(p<0.01)$ with increasing CW. Sensory flavor score was significantly increased while panel score for tenderness was decreased significantly $(p<0.001)$ with increasing CW. Consequently, CW had a positive correlation with flavor but negative correlation with tenderness. These results indicate that the increased IMF content improves flavor, juiciness and palatability, although tenderness deteriorates with increasing $\mathrm{CW}$.

Keywords: Pork carcass, Carcass weight, Heavy slaughter weight, Pork quality

\section{INTRODUCTION}

Carcass weight $(\mathrm{CW})$ is an important variable that affects pork quality and profitability of finishing pig production. CW is closely related to slaughter weight (SW). The average SW in the United States continues to grow over the past 80 years. It was $125.6 \mathrm{~kg}$ in 2013 [1] which is higher than recommended $\mathrm{SW}$ of $110 \mathrm{~kg}$ in South Korea. SW in Korea is about 5 to $15 \mathrm{~kg}$ lower than in that in Western countries as a result of an increase in genetic selection of lean-type pigs worldwide over the past few decades. Such lower SW is often considered undesirable for Korean consumers who are tolerant of animal fat. Korean meat consumers, unlike Westerners, sometimes prefer fat-rich cut such as pork belly [2].

There have been many research reports on the effect of $\mathrm{CW}$ or SW increase on pork quality and 
Acknowledgements Not applicable.

Availability of data and material Availability of data and materials Upon reasonable request, the datasets of this study can be available from the corresponding author.

Authors' contributions Conceptualization: Joo ST.

Data curation: Hwang YH.

Formal analysis: Lee SJ.

Methodology: Lee EY.

Software: Hwang YH.

Validation: Hwang YH, Lee SJ.

Investigation: Lee SJ, Lee EY.

Writing - original draft: Hwang $\mathrm{YH}$.

Writing - review \& editing: Joo ST.

Ethics approval and consent to participate This article does not require IRB/IACUC approval because there are no human and animal participants. sensory properties. However, results are inconsistent, including positive effect [3] and negative effect [4-6]. Alternatively, some studies have reported significant changes in pork quality and sensory properties with increasing SW [7,8], while others have reported no effect of SW increase [9]. Such discrepancy about the effect of SW increase among studies might be due to differences in genetics, gender and (or) age of pigs used in various experiments [10-12]. In addition, changes in pork quality with increasing CW or SW might be due to changes in muscle fiber composition and muscle metabolic traits. When live weight increased from 95 to $130 \mathrm{~kg}$, a greater total number of type I muscle fiber and their size in the longissimus muscle of pigs have been reported [7,13]. In addition, better sensory properties of pork from barrows compared to gilts could be due to greater intramuscular fat (IMF) content [14-16] and lower muscle glycolytic potential [17]. Therefore, the aim of this study was to evaluate effects of $\mathrm{CW}$ increase on meat quality and sensory properties in relation to IMF content and ultimate $\mathrm{pH}(\mathrm{pHu})$ of pork from barrows and gilts.

\section{MATERIALS AND METHODS}

\section{Animal and meat sampling}

A total of 96 pork carcasses from LYD (Landrace $\times$ Large White $\times$ Duroc) crossbred barrows (n $=48)$ and gilts $(n=48)$ were selected at a commercial slaughter house. All pigs used in the experiment were raised on the same farm with the same feed and specification methods. Each gender group had commercial CW ( $\leq 90 \mathrm{~kg}, \mathrm{CCW})$, heavy CW (91-100 kg, HCW) and very heavy CW ( $>100 \mathrm{~kg}, \mathrm{VHCW}$ ) (16 pigs for each CW group). Loin cuts were excised at $24 \mathrm{hr}$ postmortem and transported to the laboratory to measure meat color, water-holding capacity (WHC), tenderness, fat content and sensory properties.

\section{Meat quality measurements}

Backfat thickness was measured at the central part of the loin cut (the last rib area). Steaks with thickness of $3 \mathrm{~cm}$ were made in the direction from the center to the back for measuring the following in order: 1) meat color, muscle $\mathrm{pH}$, and IMF content, 2) drip loss (DL) and released water (RW), 3) cooking loss (CL) and Warner-Bratzler shear force (WBSF), and 4) sensory properties with a panel test.

The $\mathrm{pH}$ of pork loin muscle was measured using a $\mathrm{pH}$ meter (MP 230, Mettler Toledo, Greifensee, Switzerland) after mixing approximately $3.0 \mathrm{~g}$ of sample with $27 \mathrm{~mL}$ of deionized water and homogenized (T25 ULTRA-TURAX, IKA, Königswinter, Germany) for 30 seconds. The surface color of pork steaks was measured using the Minolta Chromameter (CR -300, Minolta, Tyoko, Japan). Before measurement, the instrument was standardized with a white plate $(\mathrm{Y}=93.5, \mathrm{X}=0.3132$, $\mathrm{y}=0.3198)$.

DL (\%) was measured using a plastic box method [18]. A meat sample of a standardized sized $\left(2 \mathrm{~cm}\right.$ diameter $\times 2 \mathrm{~cm}$ thickness) was hung in a plastic box $(18 \times 15 \times 10 \mathrm{~cm})$ and left in a $4^{\circ} \mathrm{C}$ refrigerator for $24 \mathrm{hrs}$. The weight loss during suspension was measured and expressed as a percentage loss based on the weight of the initial sample. CL (\%) was determined by weight loss caused by constant heat treatment on meat samples. Sample $(2 \mathrm{~cm}$ diameter $\times 2 \mathrm{~cm}$ thickness $)$ contained in a plastic bag was treated with heat in a $75^{\circ} \mathrm{C}$ water bath for 30 minutes and then the weight loss based on the initial weight was expressed as a percentage. RW (\%) was measured by the method of Joo [19]. Briefly, a meat sample $(3.0 \pm 0.05 \mathrm{~g})$ was placed between two thin plastic films and pressed with a load of $2.5 \mathrm{~kg}$, then the weight of the water drained from the original sample weight was calculated as a percentage.

WBSF $\left(\mathrm{kg} / \mathrm{cm}^{2}\right)$ was measured using an Instron Machine (Universal Testing Model 3343, In- 
stron, Norwood, MA, USA). After measuring CL, 6 shear force samples $(0.5 \mathrm{~cm} \times 4.0 \mathrm{~cm})$ per loin stake were prepared using a stainless core. Instron with a $\mathrm{V}$-shaped shear blade cut at right angles to the direction of the muscle fiber. The crosshead speed of the instrumental was set at $100 \mathrm{~mm} / \mathrm{min}$ and the maximum scale load was $50 \mathrm{~kg}$.

IMF content was determined using the Folch et al. method with some modification [20]. Briefly, a homogenized meat sample of $3 \mathrm{~g}$ was added with $30 \mathrm{ml}$ of Folch solution I (chloroform : methanol $=2: 1, \mathrm{v} / \mathrm{v}$ ) and the lipids were extracted. The solution filtered by Whatman no.1 filter paper was stirred with $0.88 \% \mathrm{NaCl}$ and separated into two layers in the cylinder. The final volume of the lower layer was recorded after washing the cylinder wall with $10 \mathrm{ml}$ of Folch solution II (chloroform : methanol : $\mathrm{H}_{2} \mathrm{O}=3: 47: 50$ ). The upper layer (methanol and water layer) was removed using an aspirator and $10 \mathrm{~mL}$ of the lower layer (chloroform containing lipid extracts) was taken into a dish to dry at $50^{\circ} \mathrm{C}$. The weight of the dish was measured before and after drying. Fat content was computed based on weight difference of the dish.

\section{Sensory evaluation}

Sensory evaluation was performed according to the modified Spectrum TM method for descriptive analysis [21] by eight trained panelists with more than $50 \mathrm{hrs}$ of experience in pork assessment. Panelists evaluated samples for flavor, juiciness, tenderness, and palatability using a 9-point hedonic scale (1 point, "extremely dislike" to 9 point, "extremely like").

\section{Statistical analysis}

This experiment had a completely randomized design with a 2 (gender; barrow vs gilt) $\times 3$ (CW; $\mathrm{CCW}$ vs HCW vs VHCW) factorial arrangement of treatments. All data of meat quality measurements and sensory evaluation were analyzed using general linear model procedure of Statistical Analysis System (SAS) ver. 9.3 [22] and a model containing gender, CW, and interaction of these terms. Significant differences were declared at $p<0.05$. Pearson Correlation coefficient was obtained to describe the relationship between $\mathrm{CW}$ and meat quality traits and sensory properties using SAS PROC.

\section{RESULTS AND DISCUSSION}

As shown in Fig. 1, backfat thickness and IMF \% increased as CW increased in both gilts and barrows. Backfat thickness and IMF \% of VHCW were significantly higher than those of CCW

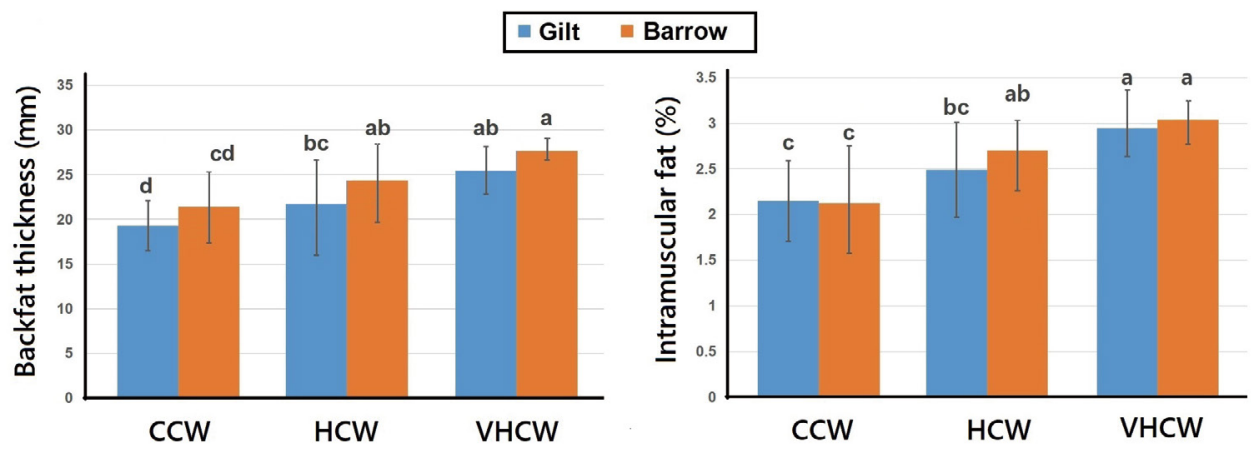

Fig. 1. Effects of carcass weight increase on backfat thickness and intramuscular fat content. Different letters in the same figure significant differences $(p<0.05)$. CCW, commercial carcass weight; HCW, heavy carcass weight; VHCW, very heavy carcass weight. 
$(p<0.05)$. There was no significant difference in IMF \% or backfat thickness between gilts and borrows. This increase of backfat thickness with increasing $\mathrm{CW}$ is similar to results of previous studies [1]. From previous 25 studies, when marketing weight of a pig was increased by $10 \mathrm{~kg}$, the backfat thickness was increased by an average of $1.8 \mathrm{~mm}$ [1]. In the present study, as CW increased by approximately $20 \mathrm{~kg}$, backfat thickness was increased by $6.0 \mathrm{~mm}$ for gilt and $6.2 \mathrm{~mm}$ for barrow. Results of relatively thicker backfat thickness and greater IMF content in barrows than in gilt were similar to results of our previous studies [2,23-25].

The $\mathrm{pHu}$ was not affected by either $\mathrm{CW}$ or gender (Table 1). Many studies have reported that $\mathrm{pH}$ does not change when SW is increased [26,27]. However, some studies have reported a slight decrease [28] or increase in $\mathrm{pH}[3,29]$ when $\mathrm{SW}$ is increased. No significant difference in $\mathrm{pHu}$ among CW groups suggests that the increase in CW will not result in an increase in PSE (pale, soft, and exudative) meat incidence due to a slow cooling rate for large carcass.

Among meat quality measurements, only ra* and WBSF showed significant $(p<0.05)$ differences among CW groups (Table 1). There was no significant difference in $L^{*}$ or $b^{*}$ values among $\mathrm{CW}$ groups. The result that $\mathrm{L}^{*}$ value was not changed with increasing $\mathrm{CW}$ was the same as our previous studies [2,24,25] and others [28,30]. However, Virgili et al. [11] have found a 0.01 unit reduction in $\mathrm{L}^{*}$ value with every $10 \mathrm{~kg}$ increase in SW. Regarding a* value, increases in $\mathrm{a}^{*}$ value with increasing CW were observed for both gilts and barrows, consistent with results of Đurkin et al. [30] and Latorre et al. [26], but different from other studies showing no significant differences in a* value with increasing $\mathrm{CW}[11,28]$. Overall, with increasing $\mathrm{CW}$ or $\mathrm{SW}$, results of $\mathrm{L}^{*}$ and $\mathrm{a}^{*}$ values were different between reports. Because meat color is the number one factor affecting consumers' decisions when purchasing meat, further studies are needed to determine changes in meat color due to $\mathrm{CW}$ increase.

As shown in Table 1, CW increase has no effect on WHC measurement. There was no significant $(p>0.05)$ difference in DL \%, CL \%, or RW \% among CW groups. The pHu was not affected by gender either, different from our previous result showing DL was greater in gilts than in barrow [2]. Although the reason for such difference between studies was unclear, DL \% in the present study was generally lower than DL \% of PSE pork which was over $5.0 \%$. This suggests that the incidence of PSE occurring at over $5.0 \%$ of DL [31] is not likely to be influenced by gender or CW. Moreover, effects of increasing SW on DL \% are inconsistent among in many studies [4,11,28,30]. In the present study, insignificant differences for all WHC measurements might be due to no difference in $\mathrm{pHu}$ among $\mathrm{CW}$ groups. This is because $\mathrm{WHC}$ is readily affected by either $\mathrm{pH}$ decline rate or $\mathrm{pHu}$.

Table 1. Differences in meat quality measurements by carcass weight increase of finishing gilts and barrows

\begin{tabular}{|c|c|c|c|c|c|c|c|c|c|c|c|}
\hline \multirow{2}{*}{ Measurements } & \multicolumn{3}{|c|}{ Gilts } & \multicolumn{3}{|c|}{ Barrows } & \multirow{2}{*}{ SEM } & \multirow{2}{*}{$p$-value } & \multicolumn{3}{|c|}{ Contrast } \\
\hline & CCW & HCW & VHCW & CCW & HCW & VHCW & & & Gender & CW & Gender $\times$ CW \\
\hline $\mathrm{pHu}$ & 5.66 & 5.68 & 5.71 & 5.67 & 5.70 & 5.78 & 0.156 & 0.3 .09 & 0.326 & 0.103 & 0.801 \\
\hline $\mathrm{CIE} \mathrm{a}^{*}$ & $7.02^{d}$ & $7.29^{\mathrm{cd}}$ & $7.71^{\mathrm{ab}}$ & $7.09^{d}$ & $7.50^{\mathrm{bc}}$ & $7.94^{\mathrm{a}}$ & 0.378 & $<0.001$ & 0.032 & $<0.001$ & 0.671 \\
\hline CIE b* & 1.97 & 1.66 & 1.69 & 1.56 & 1.59 & 1.90 & 0.734 & 0.532 & 0.552 & 0.618 & 0.249 \\
\hline Released water (\%) & 11.1 & 11.2 & 10.1 & 11.5 & 10.3 & 10.0 & 1.502 & 0.056 & 0.518 & 0.005 & 0.214 \\
\hline WBSF $\left(\mathrm{kg} / \mathrm{cm}^{2}\right)$ & $2.54^{\mathrm{c}}$ & $2.73^{\mathrm{c}}$ & $2.96^{\mathrm{ab}}$ & $2.52^{\mathrm{c}}$ & $2.75^{\mathrm{bc}}$ & $3.06^{\mathrm{a}}$ & 0.226 & $<0.001$ & 0.403 & $<0.001$ & 0.585 \\
\hline
\end{tabular}

${ }^{\mathrm{a}-\mathrm{d}} \mathrm{Means}$ with different superscripts in the same row are significantly different.

CCW, commercial carcass weight; $\mathrm{HCW}$, heavy carcass weight; VHCW, very heavy carcass weight; WBSF, Warner-Bratzler shear force; CW, carcass weight. 
Results of the present study showed that when CW increased, pork loin became tougher for both gilts and barrows (Table 1). There were significant $(p<0.05)$ differences in WBSF among $\mathrm{CW}$ groups. However, as with $\mathrm{a}^{*}$ value, there was no significant difference in WBSF between gender groups $(p>0.05)$. WBSF results with increasing CW or SW are conflicting in many studies. There is no significant difference in WBSF of pigs weighing 70, 80, 90, and $100 \mathrm{~kg}$ or 116, 124, and $133 \mathrm{~kg}$ [26]. On the contrary, a slight reduction of $0.08 \mathrm{~kg}$ per $10 \mathrm{~kg}$ marketing weight increase in WBSF has observed [4]. A quadratic effect of body weight on tenderness has also reported. Pigs weighing 140 and $160 \mathrm{~kg}$ have greater WBSF values than pigs weighing 120,150, and $170 \mathrm{~kg}$ [30]. Despite these conflicting results, our results clearly showed that when the weight of pork carcass was increased, so did the shear force of muscle. This result suggests that as pig weight increases, the tenderness decreases due to an increase ( $\mathrm{a}^{*}$ value increase) in red muscle fiber in loin muscle.

Differences in sensory properties with increasing $\mathrm{CW}$ in gilts and barrow are shown in Table 2. Flavor score was significantly increased while tenderness score was significantly decreased $(p<$ $0.05)$ with increasing CW. There were no significant difference in juiciness and palatability score among either $\mathrm{CW}$ or gender groups $(p>0.05)$. These results were different from the observation by Huff-Lonergan et al. [32]. They observed significant and positive responses of juiciness and off-flavor presence with increasing CW. Cisneros et al. [4] have observed decreased tenderness and juiciness by 0.1 and $0.4 \%$, respectively, for every $10 \mathrm{~kg}$ increase in market weight from 100 to 160 $\mathrm{kg}$. However, Park and Lee [28] have observed no significant difference in flavor profile of cooked pork when marketing weight is increased from 116 to $133 \mathrm{~kg}$.

A significant correlation between CW and sensory properties (except juiciness) was observed (Table 3). CW had a positive correlation with flavor $(r=0.59)$, while it had a negative correlation with tenderness $(r=-0.70)$. The negative correlation between $\mathrm{CW}$ and tenderness was similar to results of Martin et al. [33]. They observed a slightly positive but significant relationship between increasing CW and shear force. Both juiciness and palatability showed stronger correlations with backfat thickness ( $r=0.31$ and 0.33 , respectively) than with CW. IMF content also showed strong correlations with all sensory properties. These results indicated that an increase in fat content resulting from $\mathrm{CW}$ increase had a positive effect on sensory properties. $\mathrm{pHu}, \mathrm{L}^{*}$ and $\mathrm{DL}$ showed strong correlations with juiciness and palatability, while $\mathrm{a}^{*}$ showed significant correlations with all sensory properties. WBSF showed a strong negative correlation with tenderness, while it showed no significant correlation with palatability. These results imply that as $\mathrm{CW}$ increase, flavor improves while tenderness deteriorates. Thus, the palatability is offset without changing too much.

\section{CONCLUSIONS}

Backfat thickness and IMF content of pork loin were increased with increasing CW. $a^{*}$ value increased and shear force decreased with increasing $\mathrm{CW}$, but $\mathrm{pHu}$, lightness $\mathrm{L}^{*}$ value and all WHC

Table 2. Differences in seonsory properties by carcass weight increase of finishing gilts and barrows

\begin{tabular}{|c|c|c|c|c|c|c|c|c|c|c|c|}
\hline \multirow{2}{*}{ Measurements } & \multicolumn{3}{|c|}{ Gilts } & \multicolumn{3}{|c|}{ Barrows } & \multirow{2}{*}{ SEM } & \multirow{2}{*}{$p$-value } & \multicolumn{3}{|c|}{ Contrast } \\
\hline & CCW & $\mathrm{HCW}$ & VHCW & CCW & HCW & VHCW & & & Gender & CW & Gender $\times$ CW \\
\hline Flavor & $5.23^{c}$ & $5.72^{\mathrm{bc}}$ & $6.21^{\mathrm{ab}}$ & $5.22^{\mathrm{c}}$ & $5.98^{\mathrm{ab}}$ & $6.47^{\mathrm{a}}$ & 0.678 & $<0.001$ & 0.220 & $<0.001$ & 0.665 \\
\hline Juiciness & 5.35 & 5.65 & 5.53 & 5.41 & 5.62 & 5.82 & 0.793 & 0.596 & 0.051 & 0.286 & 0.702 \\
\hline Tenderness & $5.85^{\mathrm{a}}$ & $5.42^{\mathrm{ab}}$ & $4.73^{\mathrm{cd}}$ & $5.95^{\mathrm{a}}$ & $4.91^{\mathrm{bc}}$ & $4.27^{\mathrm{d}}$ & 0.589 & $<0.001$ & 0.018 & $<0.001$ & 0.077 \\
\hline Palatability & 5.76 & 5.73 & 5.59 & 5.62 & 5.74 & 5.97 & 0.630 & 0.595 & 0.053 & 0.837 & 0.234 \\
\hline
\end{tabular}

${ }^{a-d}$ Means with different superscripts in the same row are significantly different.

CCW, commercial carcass weight; $\mathrm{HCW}$, heavy carcass weight; $\mathrm{VHCW}$, very heavy carcass weight; $\mathrm{CW}$, carcass weight. 
Table 3. Correlation coefficients $(r)$ between sensory properties, meat quality traits and carcass weight of high-market weight pigs

\begin{tabular}{|c|c|c|c|c|}
\hline Measurements & Flavor & Juiciness & Tenderness & Palatability \\
\hline Carcass weight & $0.59^{* * * t}$ & 0.28 & $-0.70^{\text {t** }}$ & $0.20^{*}$ \\
\hline Backfat thickness & $0.50^{* *+*}$ & $0.31^{* *}$ & $-0.56^{*+* x}$ & $0.33^{* * * *}$ \\
\hline IMF (\%) & $0.55^{*+*}$ & $0.26^{*}$ & $-0.58^{*+*}$ & $0.22^{*}$ \\
\hline $\mathrm{pHu}$ & 0.15 & $0.65^{*+*+1}$ & $-0.22^{*}$ & $0.57^{* * *}$ \\
\hline $\mathrm{CIE} \mathrm{L}^{*}$ & -0.11 & $-0.64^{* * * *}$ & $0.22^{*}$ & $-0.53^{\text {t*t* }}$ \\
\hline CIE $a^{*}$ & $0.51^{* * *}$ & $0.35^{*+*+}$ & $-0.43^{+*+*}$ & $0.35^{*+*+*}$ \\
\hline CIE $b^{*}$ & -0.06 & 0.03 & -0.02 & 0.04 \\
\hline Drip loss (\%) & -0.14 & -0.74 & $0.25^{*}$ & $-0.61^{* * *}$ \\
\hline Cooking loss (\%) & -0.19 & -0.19 & 0.16 & -0.13 \\
\hline Released water (\%) & -0.15 & -0.15 & $0.28^{* *}$ & -0.19 \\
\hline WBSF & $0.49^{*+*}$ & $0.24^{*}$ & $-0.85^{*+*}$ & 0.18 \\
\hline
\end{tabular}

$p<0.05, " p<0.01, " p<0.001$.

IMF, intramuscular fat; WBSF, Warner-Bratzler shear force.

measurements did not changed. As CW increase, sensory flavor score increased while tenderness score decreased. Consequently, $\mathrm{CW}$ has a positive correlation with flavor but negative correlation with tenderness. The increase in IMF content resulting from CW increase improves flavor, juiciness and palatability, although tenderness deteriorates with increasing CW. Therefore, an increase in $\mathrm{CW}$ is expected to improve the taste of pork.

\section{REFERENCES}

1. Wu F, Vierck KR, DeRouchey JM, O'Quinn TG, Tokach MD, Goodband RD, et al. A review of heavy weight market pigs: status of knowledge and future needs assessment. Transl Anim Sci. 2017;1:1-15. https://doi.org/10.2527/tas2016.0004

2. Jeong JY, Park BC, Ha DM, Park MJ, Joo ST, Lee CY. Effects of increasing slaughter weight on production efficiency and carcass quality of finishing gilts and barrows. Korean J Food Sci Anim Resour. 2010;30:206-15. https://doi.org/10.5851/kosfa.2010.30.2.206

3. Piao JR, Tian JZ, Kim BG, Choi YI, Kim YY, Han IK. Effects of sex and market weight on performance, carcass characteristics and pork quality of market hogs. Asian-Australas J Anim Sci. 2004;17:1452-8. https://doi.org/10.5713/ajas.2004.1452

4. Cisneros F, Ellis M, McKeith FK, McCaw J, Fernando RL. Influence of slaughter weight on growth and carcass characteristics, commercial cutting and curing yields, and meat quality of barrows and gilts from two genotypes. J Anim Sci. 1996;74:925-33. https://doi. org/10.2527/1996.745925x

5. Ellis M, Webb AJ, Avery PJ, Brown I. The influence of terminal sire genotype, sex, slaughter weight, feeding regime and slaughter-house on growth performance and carcass and meat quality in pigs and on the organoleptic properties of fresh pork. Anim Sci. 1996;62:521-30. https://doi.org/10.1017/S135772980001506X

6. Čandek-Potokar M, Lefaucheur L, Žlender B, Bonneau M. Effect of slaughter weight and/ or age on histological characteristics of pig longissimus dorsi muscle as related to meat quality. Meat Sci. 1999;52:195-203. https://doi.org/10.1016/S0309-1740(98)00168-5

7. Choi YM, Oh HK. Carcass performance, muscle fiber, meat quality, and sensory quality characteristics of crossbred pigs with different live wights. Korean J Food Sci Anim Resour. 
2016;36:389-96. https://doi.org/10.5851/kosfa.2016.36.3.389

8. Kim YS, Kim SW, Weaver MA, Lee CY. Increasing the pig market weight: world trends, expected consequences and practical considerations. Aisan-Australas J Anim Sci. 2005;18:590600. https://doi.org/10.5713/ajas.2005.590

9. Malmfors B, Lundström K, Hansson I. Fatty acid composition of porcine back fat and muscle lipids as affected by sex, weight and anatomical locations [Swedish Landrace, Swedish Yorkshire]. Swed J Agric Res. 1978;8:25-38.

10. Minelli G, Culioli J, Vignon X, Monin G. Postmortem changes in the mechanical properties and ultra-struture of the longissimus in two porcine breeds. J Muscle Foods. 1995;6:313-26. https://doi.org/10.1111/j.1745-4573.1995.tb00577.x

11. Virgili R, Degni M, Schivazappa C, Faeti V, Poletti E, Marchetto G, et al. Effect of age at slaughter on carcass traits and meat quality of Italian heavy pigs. J Anim Sci. 2003;81:2448-56. https://doi.org/10.2527/2003.81102448x

12. Gil M, Delday MI, Gispert M, Furnols MF, Maltin CM, Plastow GS, et al. Relationships between biochemical characteristics and meat quality of Longissimus thoracis and Semimembranosus muscles in five porcine lines. Meat Sci. 2008;80:927-33. https://doi.org/10.1016/ j.meatsci.2008.04.016

13. Choi YM, Nam KW, Choe JH, Ryu YC, Wick MP, Lee K, et al. Growth, carcass fiber type, and meat quality characteristics in large white pigs with different live weights. Livest Sci. 2013;155:123-9. https://doi.org/10.1016/j.livsci.2013.02.009

14. Correa JA, Faucitano L, Laforest JP, Rivest J, Marcoux M, Gariépy C. Effects of slaughter weight on carcass composition and meat quality in pigs of two different growth rates. Meat Sci. 2006;72:91-9. https://doi.org/10.1016/j.meatsci.2005.06.006

15. Newcom D, Stalder KJ, Bass TJ, Goodwin RN, Parrish FC, Wiegand BR. Breed differences and genetic parameters of myoglobin concentration in porcine longissimus muscle. J Anim Sci. 2004;82:2264-8. https://doi.org/10.2527/2004.8282264x

16. Latorre MA, Ripoll G, García-Belenguer E, Ariño L. The effect of gender and slaughter weight on loin and fat characteristics of pigs intended for Teruel dry-cured ham production. Span J Agric Res. 2009;7:407-16. https://doi.org/10.5424/sjar/2009072-1648

17. Larzul C, Lefaucheur L, Ecolan P, Gogué J, Talmant A, Sellier P, et al. Penotypic and genetic parameters for longissimus muscle fiber characteristics in relation to growth, carcass, and meat quality traits in large white pigs. J Anim Sci. 1997;75:3126-37. https://doi. org/10.2527/1997.75123126x

18. Joo ST, Lee JI, Ha YL, Park GB. Effects of dietary conjugated linoleic acid on fatty acid composition, lipid oxidation, color, and water-holding capacity of pork loin. J Anim Sci. 2002;80:108-12. https://doi.org/10.2527/2002.801108x

19. Joo ST. Determination of water-holding capacity of porcine musculature based on released water method using optimal load. Korean J Food Sci Anim Resour. 2018;38:823-8. https://doi. org/ 10.5851/kosfa.2018.e18

20. Folch J, Lees M, Sloane-Stanley GH. A simple method for the isolation and purification of total lipides from animal tissues. J Biol Chem. 1957;226:497-509.

21. Meilgaard MC, Civille GV, Carr BT. Sensory evaluation techniques. 4th ed. Boca Raton, FL: CRC Press; 2006.

22. SAS Institute. SAS/STAT user's guide. Version 9. Cary, NC: SAS Institute; 2002.

23. Lee EY, Lee SJ, Hwang YH, Kang HJ, Joo ST. Influences of gender on meat quality, electronic tongue measurements and sensory characteristics of pork loin. Ann Anim Resour Sci. 2019;30:165-71. https://doi.org/10.12718/AARS.2019.30.4.165 
24. Park MJ, Ha DM, Shin HW, Lee SH, Kim WK, Ha SH, et al. Growth efficiency, carcass quality characteristics and profitability of 'high'-market weight pigs. J Anim Sci Technol. 2007;49:459-70. https://doi.org/10.5187/JAST.2007.49.4.459

25. Park MJ, Jeong JY, Ha DM, Park JW, Sim TG, Yang HS, et al. Relationships of the slaughter weight to growth performance and meat quality traits in finishing pigs fed a low-energy diet. J Anim Sci Technol. 2009;51:135-42. https://doi.org/10.5187/JAST.2009.51.2.135

26. Latorre MA, Lázaro R, Valencia DG, Medel P, Mateos GG. The effects of gender and slaughter weight on the growth performance, carcass traits and meat quality characteristics of heavy pigs.J Anim Sci. 2004;82:526-33. https://doi.org/10.2527/2004.822526x

27. Leach LM, Ellis M, Sutton DS, Mckeith FK, Wilson ER. The growth performance, carcass characteristics, and meat quality of halothane carrier and negative pigs. J Anim Sci. 1996;74:934-43. https://doi.org/10.2527/1996.745934x

28. Park B, Lee C. Feasibility of increasing the slaughter weight of finishing pigs.J Anim Sci Technol. 2011;53:211-22. https://doi.org/10.5187/JAST.2011.53.3.211

29. Bertol TM, Oliveira EA, Coldebella A, Kawski VL, Scandolera AJ, Warpechowski MB. Meat quality and cut yield of pigs slaughtered over $100 \mathrm{~kg}$ live weight. Arq Bras Med Vet Zootec. 2015;67:1166-74. https://doi.org/10.1590/1678-4162-8113

30. Đurkin I, Dadić M, Brkić D, Lukić B, Kušec G, Mikolin M, et al. Influence of gender and slaughter weight on meat quality traits of heavy pigs. Acta Agric Slov. 2012;Supppl 3:211-4.

31. Joo ST, Kauffman RG, Kim BC, Park GB. The relationship of sarcoplasmic and myofibrillar protein solubility to colour and water-holding capacity in porcine longissimus muscle. Meat Sci. 1999;52:291-7. https://doi.org/10.1016/S0309-1740(99)00005-4

32. Huff-Lonergan E, Bass TJ, Malek M, Dekkers CM, Prusa K, Rothschild MF. Correlations among selected pork quality traits. J Anim Sci. 2002;80:617-27. https://doi. org/10.2527/2002.803617x

33. Martin AH, Sather AP, Fredeen HT, Jolly RW. Alternative market weights for swine. II. Carcass composition and meat quality. J Anim Sci. 1980;50:699-705. https://doi.org/10.2527/ jas1980.504699x 